\title{
FAKTOR-FAKTOR YANG MEMENGARUHI PERILAKU MENABUNG DI KALANGAN MAHASISWA
}

\author{
Hani Sirine \\ Fakultas Ekonomika dan Bisnis, Universitas Kristen Satya Wacana Salatiga \\ hani.sirine@staff.uksw.edu \\ Dwi Setiyani Utami \\ Alumnus Magister Sains Program Manajemen \\ Fakultas Ekonomika dan Bisnis, Universitas Gadjah Mada Yogyakarta \\ dwiutami85@gmail.com
}

\begin{abstract}
High growth rate of savings will increase the rate of investment in Indonesia and encourage the economic growth of a nation. But according to the survey conducted by Otoritas Jasa Keuangan (OJK), people is still have a low understanding of the use of financial products including savings. It is also shown on the position of the savings that experienced declining growth from 2009-2013, especially in Central Java Province. Students as the academic community are expected to have a good understanding on the choice of investment and consumption so that students can contribute to the economic growth of Indonesia. Several of previous studies showed that financial literacy, socialization of parents, peers influence, and self-control have a significant positive effect on student savings behavior. The purpose of this study is going to reexamine the results of previous studies with a sample of 221 students of FEB in Satya Wacana Christian University. The results showed that financial literacy, socialization of parents, peers influence, and self-control simultaneously have a significant effect on savings behavior. Partially, financial literacy, socialization of parents, and self-control have a positive significant effect on savings behavior of students, but peers influence have no significant effect.
\end{abstract}

Keywords: financial literacy, socialization of parents, peers influence, self-control, savings behavior

\begin{abstract}
ABSTRAK
Tingkat pertumbuhan tabungan yang tinggi akan meningkatkan laju investasi di Indonesia dan mendorong pertumbuhan ekonomi suatu bangsa. Survei yang dilakukan oleh Otoritas Jasa Keuangan (OJK), menunjukkan orang masih memiliki pemahaman yang rendah mengenai penggunaan produk keuangan termasuk tabungan. Hal ini juga ditunjukkan oleh posisi tabungan yang mengalami pertumbuhan menurun dari 20092013, terutama di Provinsi Jawa Tengah. Mahasiswa sebagai civitas akademika diharapkan memiliki pemahaman yang baik pada pilihan investasi dan konsumsi sehingga mahasiswa dapat berkontribusi terhadap pertumbuhan ekonomi Indonesia. Beberapa penelitian sebelumnya menunjukkan bahwa melek finansial, sosialisasi orang
\end{abstract}


tua, pengaruh rekan-rekan, dan kontrol diri memiliki efek positif yang signifikan terhadap perilaku tabungan mahasiswa. Tujuan dari penelitian ini adalah menguji kembali hasil penelitian sebelumnya dengan menggunakan sampel sebanyak 221 mahasiswa FEB Universitas Kristen Satya Wacana. Hasil penelitian menunjukkan bahwa melek finansial, sosialisasi dari orang tua, pengaruh rekan-rekan, dan kontrol diri secara bersamaan memiliki pengaruh yang signifikan terhadap perilaku tabungan. Secara parsial, melek finansial, sosialisasi dari orang tua, dan kontrol diri memiliki pengaruh yang signifikan positif terhadap perilaku tabungan mahasiswa, tetapi pengaruh rekan-rekan tidak berpengaruh secara signifikan.

Kata kunci: literasi keuangan, sosialisasi orang tua, pengaruh rekan-rekan, kontrol diri, perilaku menabung

\section{PENDAHULUAN}

Negara dengan tingkat tabungan yang tinggi akan menjadi negara dengan perekonomian yang kuat karena pertumbuhan ekonomi akan ditopang oleh investasi (Rustow 1967). Penelitian Athukorala dan Sen (2004) menyatakan bahwa pertumbuhan pendapatan per kapita mempunyai hubungan positif signifikan terhadap tingkat tabungan masyarakat. Semakin banyak yang dapat ditabung dan kemudian diinvestasikan, maka laju pertumbuhan perekonomian akan semakin cepat (Todaro 1983).

Dalam teori pembangunan, Keynes (1936) menyatakan bahwa tabungan merupakan bagian dari pendapatan suatu periode tertentu yang tidak habis dikonsumsi pada periode bersangkutan. Menurut Teori absolute income oleh Keynes, kemampuan menabung umumnya dipengaruhi oleh faktor-faktor ekonomi seperti pendapatan bersih per kapita (Mankiw 2007). Pertumbuhan ekonomi bisa terjadi dengan pesat, jika setiap negara mencadangkan atau menabung sebagian tertentu dari pendapatan nasionalnya (Gross Domestic Product) untuk menambah atau menggantikan barang-barang modal yang telah susut atau rusak (Harrod 1939; Domar 1946).

Pertumbuhan ekonomi daerah dapat dicerminkan dari perubahan Produk Domestik Regional Bruto (PDRB) dalam suatu wilayah. Laju pertumbuhan ekonomi di Jawa Tengah selama kurun waktu lima tahun terakhir (2009-2013) ini mengalami ratarata kenaikan sebesar 6,01 persen (BPS 2013). Seiring dengan hal tersebut, posisi tabungan di Jawa Tengah juga mengalami pertumbuhan dari tahun 2009-2013, seperti ditunjukkan Tabel 1 berikut ini:

Tabel 1

Posisi Tabungan di Jawa Tengah

\begin{tabular}{ccc}
\hline Tahun & Jumlah Tabungan & Pertumbuhan (\%) \\
\hline 2009 & Rp45.317 miliar & \\
2010 & Rp55.991 miliar & $23,6 \%$ \\
2011 & Rp68.942 miliar & $23,1 \%$ \\
2012 & Rp83.950 miliar & $21,8 \%$ \\
2013 & Rp95.704 miliar & $14,0 \%$ \\
\hline Sumber: Statistik Ekonomi - Keuangan Daerah, Provinsi Jawa Tengah, Bank Indonesia (2013)
\end{tabular}

Sumber: Statistik Ekonomi - Keuangan Daerah, Provinsi Jawa Tengah, Bank Indonesia (2013) 
Menurut teori pertumbuhan neoklasik tradisional (traditional neoclassical growth theory), pertumbuhan ekonomi atau output itu selalu bersumber dari satu atau lebih dari tiga faktor: kenaikan kuantitas dan kualitas tenaga kerja (melalui pertumbuhan jumlah penduduk dan perbaikan pendidikan), penambahan modal (melalui tabungan dan investasi), serta penyempurnaan teknologi (Todaro 1983). Hasil penelitian Susetyo (2011) menunjukkan bahwa tingkat investasi, aglomerasi, tenaga kerja dan indeks pembangunan manusia memiliki kecenderungan hubungan searah dengan pertumbuhan ekonomi. Hal ini mengindikasikan bahwa tingkat investasi, aglomerasi, tenaga kerja dan indeks pembangunan manusia sejalan dengan kenaikan pertumbuhan ekonomi.

Di lain pihak, survei Otoritas Jasa Keuangan (OJK) pada 20 provinsi di Indonesia yang melibatkan 8.000 responden, menunjukkan tingkat literasi keuangan masyarakat masih rendah. Tercatat baru 22 persen responden yang memahami jasa perbankan, 18 persen paham tentang produk dan jasa asuransi, 15 persen responden memahami pegadaian, 10 persen memahami lembaga pembiayaan, serta 7 persen yang memahami dana pensiun. Pemahaman terendah terjadi di pasar modal, karena hanya 4 persen responden yang memahami. Pemahaman yang rendah akan produk-produk keuangan mengakibatkan tingkat pemanfaatan produk-produk tersebut juga rendah (http://investar.idx.co.id).

Penelitian tentang perilaku menabung telah dilakukan oleh beberapa peneliti, dimana perilaku menabung sering dihubungkan dengan melek finansial (Sabri \& MacDonald 2010; Ming Thung et al., 2012; Cude et al., 2006; Wahana 2014). Selain melek finansial, perilaku menabung juga dihubungkan dengan pengaruh sosial seperti peran orang tua dan teman sebaya. Hal tersebut dapat dilihat dalam penelitian Cude et al. (2006), Furnham (1999), Lim, Sia, dan Gan (2011), Ming Thung et al. (2012) dan Otto (2009). Penelitian Cude et al. (2006) dan Sabri dan MacDonald (2010) menghasilkan temuan bahwa perilaku seseorang dalam menabung dipengaruhi oleh masalah atau risiko keuangan yang pernah dialami seseorang. Beberapa peneliti mengikutsertakan variabel kontrol diri sebagai salah satu faktor yang memengaruhi perilaku menabung, di antaranya penelitian Lim et al. (2011), Ming Thung et al. (2012) dan Wahana (2014).

Penelitian ini ingin menguji kembali bagaimana perilaku menabung dilihat dari melek finansial (Sabri \& MacDonald 2010; Ming Thung et al., 2012; Cude et al., 2006; Wahana 2014), pengaruh sosial seperti peran orang tua dan teman sebaya (Ming Thung et al., 2012; Lim, Sia, \& Gan 2011; Otto 2009; Cude et al., 2006; Furnham 1999) dan kontrol diri (Ming Thung et al., 2012; Lim, Sia, \& Gan 2011; Wahana 2014). Untuk indikator-indikator empirik yang digunakan dalam variabel-variabel penelitian berasal dari penelitian Ming Thung et al. (2012).

Ming Thung et al. (2012) menguji perilaku menabung pada para mahasiswa di 4 (empat) perguruan tinggi negeri dan 2 (dua) perguruan tinggi swasta di Malaysia dengan sampel 420 mahasiswa. Sampel dalam penelitian ini adalah mahasiswa Fakultas 
Ekonomika dan Bisnis Universitas Kristen Satya Wacana Salatiga (FEB UKSW). Mahasiswa sebagai bagian dari masyarakat terpelajar memiliki peran penting dalam pertumbuhan ekonomi suatu negara. Sebelum melakukan pengambilan keputusan baik itu konsumsi maupun investasi, mahasiswa diharapkan memiliki pemahaman yang baik atas pilihan yang dilakukan. Variabel melek finansial, sosialisasi orang tua, pengaruh teman sebaya dan kontrol diri diujikan kepada mahasiswa untuk mengetahui perilaku menabung mereka.

Adapun persoalan dalam penelitian ini adalah: Seperti apa pengaruh melek finansial terhadap perilaku menabung di kalangan mahasiswa FEB UKSW? Seperti apa pengaruh sosialisasi orang tua terhadap perilaku menabung di kalangan mahasiswa FEB UKSW? Seperti apa pengaruh teman sebaya terhadap perilaku menabung di kalangan mahasiswa FEB UKSW? Seperti apa pengaruh kontrol diri terhadap perilaku menabung di kalangan mahasiswa FEB UKSW?

Manfaat penelitian ini bagi mahasiswa adalah agar mahasiswa menjaga perilaku hemat efektif dengan cara meningkatkan literasi keuangan sehingga memungkinkan mereka dapat mengelola uang secara bijak. Bagi Fakultas Ekonomika dan Bisnis Universitas Kristen Satya Wacana Salatiga, hasil penelitian ini diharapkan dapat memberi stimulus bagi perguruan tinggi agar mengembangkan program pendidikan keuangan yang efektif berdasarkan kebutuhan dan tingkat melek finansial mahasiswa.

Penyelenggaraan seminar atau workshop dapat menjadi cara alternatif untuk meningkatkan pengetahuan keuangan, sikap dan perilaku mahasiswa. Selain itu, perguruan tinggi juga dapat secara aktif mengatur sosialisasi keuangan atau mengadakan pembicaraan yang melibatkan orang tua guna mendorong mereka mengkomunikasikan masalah keuangan antara orang tua dan anak-anak mereka. Dalam hal ini perguruan tinggi juga tidak mengabaikan kontrol diri sebagai keterampilan penting bagi mahasiswa untuk melakukan manajemen keuangan yang sehat. Program pendidikan dapat mengembangkan strategi bagi mahasiswa untuk mempertahankan kontrol diri.

\section{KAJIAN PUSTAKA DAN PERUMUSAN HIPOTESIS}

Theory of Planned Behavior (TPB) yang diperkenalkan oleh Icek Ajzen pada tahun 1991, merupakan pengembangan dari Theory of Reasoned Action yang dirumuskan bersama oleh Ajzen dan Fishbein (Ajzen \& Fishbein 1980; Fishbein \& Ajzen 1975). Secara umum, teori tersebut menjelaskan mengapa seseorang melakukan tindakan tertentu. TPB telah digunakan dalam beberapa bidang seperti penelitian sistem informasi (Mathieson 1991; Pavlou \& Fygenson 2006), penelitian yang berhubungan dengan kesehatan (Pellino 1997), ekonomi (Cook, Kerr, \& Moore 2002) serta sumber daya manusia (Wiethoff 2004).

Ada tiga konsep yang terdapat dalam TPB, di antaranya: sikap terhadap perilaku (attitude towards the behaviour), norma subjektif (subjective norm) dan kontrol perilaku 
yang dirasakan (perceived behavioural control). Pertama, sikap terhadap perilaku mengacu pada tingkat di mana seseorang membentuk evaluasi positif atau negatif terhadap perilaku. Sementara itu, norma subjektif mengacu pada tekanan sosial yang dirasakan untuk melakukan atau tidak melakukan perilaku tersebut. Tekanan sosial berasal dari referensi yang menonjol seperti orang tua, pasangan, teman dan kolega. Untuk kontrol perilaku yang dirasakan mengacu pada persepsi orang tentang kemampuan mereka dalam melakukan perilaku tertentu. Ini menyiratkan niat seseorang untuk melakukan tindakan tertentu diprediksi oleh persepsi kemudahan atau kesulitan melakukan perilaku tersebut dan diasumsikan mencerminkan pengalaman masa lalu serta hambatan yang dapat diantisipasi.

Dalam konteks ekonomi, tabungan didefinisikan sebagai sisa pendapatan setelah dikurangi konsumsi selama periode waktu tertentu (Browning \& Lusardi 1996; Warneryd 1999). Sebaliknya, menabung dalam konteks psikologis disebut proses dengan tidak menghabiskan uang untuk periode saat ini untuk digunakan di masa depan (Warneryd 1999). Dengan kata lain, perilaku menabung adalah kombinasi dari persepsi kebutuhan masa depan, keputusan menabung dan tindakan penghematan. Sebagian besar, orang cenderung untuk mendefinisikan tabungan sebagai investasi, menempatkan uang di rekening bank, berspekulasi dan melunasi hipotek (Warneryd 1999).

Penelitian ini erat kaitannya dengan tiga konsep yang terdapat dalam TPB. Konsep sikap terhadap perilaku tercermin melalui variabel melek finansial, sedangkan norma subjektif dan kontrol perilaku tercermin melalui variabel sosialisasi orang tua, pengaruh teman sebaya, kontrol diri dan perilaku menabung mahasiswa. Menurut Assael (1998) sikap terdiri dari tiga komponen utama yaitu cognitive component, affective component dan conative component. Komponen kognitif melibatkan think, understanding dan awareness. Komponen afektif berkaitan dengan feeling, evaluating, interest dan desire. Untuk komponen konatif melibatkan acting, behaviors dan purchase action. Dari ketiga komponen tersebut melek finansial merupakan komponen yang terlibat dengan sikap karena termasuk dalam komponen kognitif.

Melek finansial merupakan faktor penting dalam menentukan perilaku menabung dan masalah keuangan (Sabri, M.F., MacDonald, M., Masud, Jariah, Paim, L. Hira, T.K. 2008). Anthes (2000) mendefinisikan melek finansial sebagai kemampuan membaca, menganalisis, mengelola dan berkomunikasi tentang kondisi keuangan pribadi yang memengaruhi materi kesejahteraan. Peneliti lain (Lusardi 2005, 2008; Delafrooz \& Paim 2011) menyatakan bahwa melek finansial sebagai penentu utama perilaku menabung. Delafrooz dan Paim (2011) telah melakukan penelitian di Malaysia untuk menguji sejauh mana melek finansial memengaruhi perilaku menabung. Penelitian ini telah dilakukan melalui metodologi kuantitatif dengan menyebarkan kuesioner kepada 2.246 karyawan di sektor publik dan swasta. Temuan ini menunjukkan bahwa perilaku menabung secara signifikan dipengaruhi oleh melek finansial di mana individu yang tingkat melek finansialnya rendah tidak mudah untuk menabung dan akhirnya mengalami masalah keuangan di masa depan. 
Bukti empiris dari penelitian Otto (2009) menunjukkan bahwa orang tua memiliki peran dalam mendorong anak-anak untuk memiliki keterampilan menabung. Kuesioner penelitian yang berisi pengelolaan keuangan siswa ini diberikan kepada 446 siswa berusia 13 sampai 14 tahun di Devon, Inggris. Hal tersebut didukung oleh penelitian Webley dan Nyhus (2006) yang menghasilkan temuan bahwa perilaku orang tua memengaruhi perilaku ekonomi anak-anak. Perilaku orang tua dan orientasi orang tua memiliki perilaku yang lemah namun signifikan dampaknya terhadap perilaku anak-anak di masa dewasa. Penelitian ini memberikan informasi rinci tentang perilaku keuangan dan berbagai konsep psikologis orang tua dan anak-anak. Lain lagi dengan penelitian yang dilakukan oleh Furnham (1999) yang menganalisis tentang perilaku menabung dan berbelanja anak-anak muda. Kuesioner diberikan kepada 158 laki-laki dan 122 perempuan di South East of England. Hasil penelitian menunjukkan bahwa perilaku hemat anak-anak muda disebabkan oleh permintaan dan persyaratan orang tua.

Sebuah studi yang dilakukan Erskine, Kier, Leung, dan Sproule (2006) di Toronto, Kanada dengan sampel 1.806 anak muda Kanada berusia 12 sampai 24 tahun tentang perilaku menabung ditemukan bahwa pengaruh teman sebaya memiliki dampak pada perilaku individu untuk berhemat. Hal tersebut sejalan dengan penelitian Tooth (2006) yang menghasilkan temuan bahwa perilaku konsumsi seseorang dipengaruhi oleh pilihan konsumsi rekan-rekannya. Begitu pula Inkeles (1969) yang menyatakan bahwa kelompok sebaya memiliki pengaruh besar terhadap para remaja.

Penentu penting lain dari perilaku menabung dan pengeluaran individu adalah kontrol diri. Hal ini dapat dilihat dari literatur psikologi ekonomi maupun ekonomi. Dalam penelitian Esenvalde (2011) telah memberikan bukti empiris bahwa kontrol diri positif memengaruhi perilaku hemat. Dalam penelitian ini, menggunakan metoda snowball sampling dengan total sampel 272 karyawan yang memiliki pendapatan tetap di Amerika Serikat. Kontrol diri adalah kemampuan untuk mengidentifikasi dan mengatur emosi dan keinginan seseorang. Hal ini ditandai dengan disiplin diri dan kemampuan untuk menunda kepuasan (Baumeister 2002). Menurut Lim et al. (2011), terdapat dampak yang signifikan dari kontrol diri terhadap perilaku hemat. Penelitian tersebut dilakukan di Malaysia dengan 500 kuesioner dibagikan kepada responden yang berusia di atas 21 tahun. Dalam studi tersebut, para peneliti menemukan bahwa kemampuan individu untuk mempertahankan kontrol diri dalam berhemat tergantung pada dua kekuatan yang berlawanan yang dikenal sebagai keinginan dan kemauan. Temuan tersebut menunjukkan bahwa orang lebih cenderung untuk menabung jika mereka mampu mengendalikan diri melalui penerapan penganggaran dan penilaian biaya ekonomi.

Dalam studi Otto (2009) menunjukkan langkah-langkah yang dilakukan guna meningkatkan pemahaman tentang menabung selama masa remaja. Namun, penelitian tersebut juga mengkaji apakah remaja memiliki kebiasaan boros atau menemukan kesulitan dalam menahan godaan. Dari hasil penelitian, ditemukan bahwa kesadaran dikaitkan dengan sikap positif terhadap menabung (Nyhus 2002) dan pengendalian diri terhadap keuangan (Warneryd 1999). Selain itu, ditemukan bahwa variabel psikologis 
yaitu kontrol diri dan kemampuan untuk menunda kepuasan merupakan keterampilan penting untuk menabung ketika berusia muda. Penelitian dilakukan dengan sampel 290 mahasiswa dari dua perguruan tinggi di Inggris yaitu Exmouth Community College dan Clyst Vale Community College.

\section{Perumusan Hipotesis}

Garman dan Forgue (2006) mendefinisikan melek finansial sebagai pengetahuan yang cukup tentang fakta-fakta keuangan pribadi dan istilah untuk pengelolaan keuangan pribadi yang sukses. Penelitian Delafrooz dan Paim (2011) dengan sampel karyawan di sektor publik dan swasta menunjukkan bahwa individu yang tingkat melek finansialnya rendah tidak mudah untuk menabung dan akhirnya mengalami masalah keuangan di masa depan. Hal tersebut didukung oleh Sabri dan MacDonald (2010) yang menguji melek finansial di kalangan mahasiswa. Hasil penelitian Sabri dan MacDonald (2010) menunjukkan bahwa mahasiswa yang memiliki pengetahuan yang besar pada keuangan pribadi cenderung memiliki perilaku hemat efektif. Dengan demikian, hipotesis pertama yang diusulkan adalah sebagai berikut.

H1: Melek finansial berpengaruh signifikan terhadap perilaku menabung di kalangan mahasiswa.

Penelitian Cude et al. (2006) menemukan bahwa orang tua memainkan peran sentral dalam sosialisasi keuangan anak-anak mereka. Hal tersebut didukung oleh penelitian terdahulu (Otto 2009; Furnham 1999) yang menyatakan bahwa perilaku orang dewasa muda terkait hubungan mereka dengan orang tua. Sosialisasi orang tua tentang dampak positif menabung dan pentingnya membudayakan perilaku menabung menjadi faktor penunjang perilaku anak dalam keputusan investasi dan konsumsi mereka. Mischel (1961) juga membuktikan bahwa orang tua yang memberi pengetahuan dan skill menabung akan memengaruhi perilaku menabung anak-anak mereka. Oleh karena itu hipotesis kedua yang diusulkan adalah sebagai berikut.

H2: Sosialisasi orang tua berpengaruh signifikan terhadap perilaku menabung di kalangan mahasiswa.

Tooth (2006) melakukan sebuah survei yang menghasilkan temuan bahwa perilaku konsumsi seseorang dipengaruhi oleh pilihan konsumsi rekan-rekannya. Hal ini sejalan dengan pendapat Inkeles (1969) yang menyatakan bahwa kelompok sebaya memiliki pengaruh besar terhadap para remaja. Youniss dan Haynie (1992) juga menyatakan bahwa teman sebaya dan sosialisasi orang tua berpengaruh kuat terhadap perilaku orang dewasa muda. Penelitian Otto (2009) memperkuat temuan itu, yaitu perilaku menabung orang dewasa muda lebih berorientasi rekan-rekan mereka serta dunia orang dewasa atau kurang bergantung pada orang tua. Dengan demikian, hipotesis ketiga yang diusulkan adalah sebagai berikut:

H3: Pengaruh teman sebaya berpengaruh signifikan terhadap perilaku menabung di kalangan mahasiswa 
Beberapa penelitian terdahulu (Ainslie 1975; Strotz 1955; Wood 1998; Warneryd 1999) menyatakan bahwa kontrol diri memengaruhi keputusan ekonomi dan keputusankeputusan lainnya. Menurut Lim et al. (2011), seseorang yang memiliki kontrol diri yang kuat akan mampu untuk berhemat. Hal ini disebabkan oleh pertentangan dalam diri atas kebutuhan dan keinginan. Kontrol diri yang baik akan termanifestasi melalui aktivitas penganggaran dan penilaian atas biaya ekonomi. Penelitian Webley dan Nyhus (2006) serta Wahana (2014) juga menunjukkan hal yang sama yaitu salah satu variabel yang memengaruhi perilaku menabung yang baik adalah kontrol diri yang kuat atas keputusankeputusan invetasi dan konsumsi individu. Oleh karena itu hipotesis keempat yang diusulkan dalam penelitian ini adalah sebagai berikut:

H4: Kontrol diri berpengaruh signifikan terhadap perilaku menabung di kalangan mahasiswa

\section{Model Penelitian}

Model dalam penelitian ini disajikan pada gambar 1 berikut.

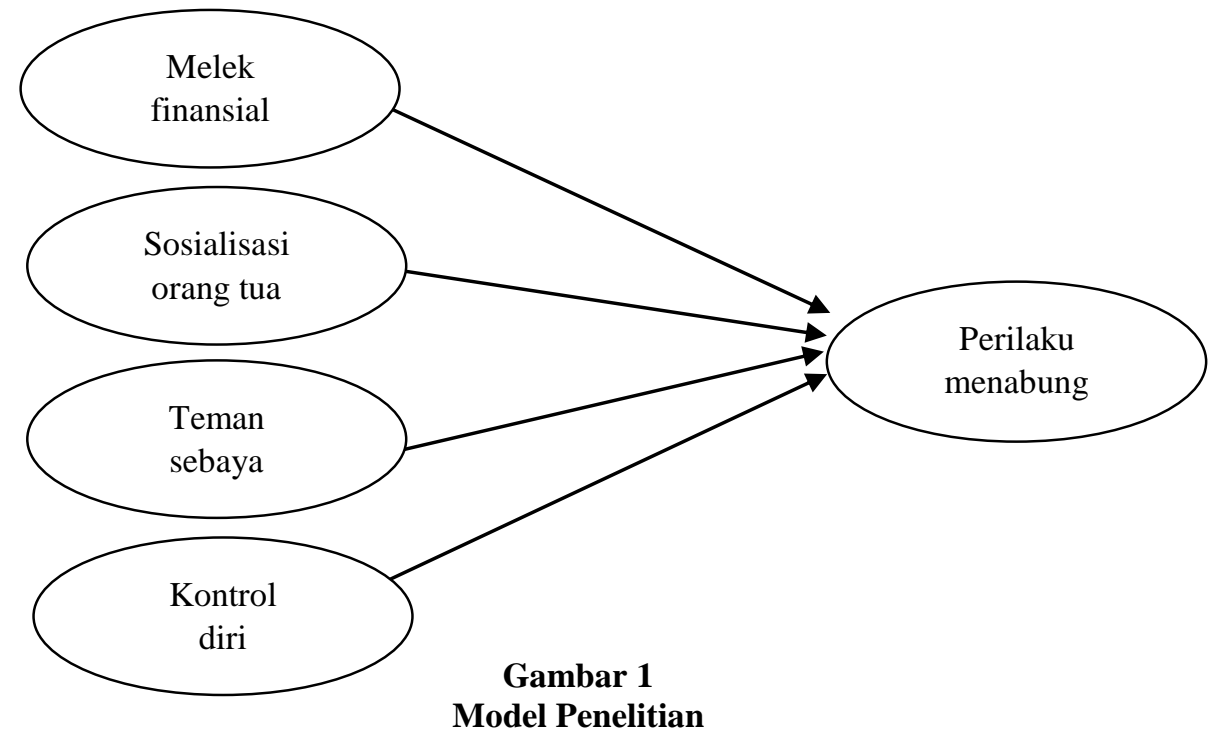

\section{METODA PENELITIAN}

\section{Jenis dan Sumber Data}

Data berupa hasil kuesioner kepada 303 mahasiswa Fakultas Ekonomika dan Bisnis Universitas Kristen Satya Wacana yang berisi tentang variabel-variabel dalam penelitian ini yaitu melek finansial, sosialisasi orang tua, pengaruh teman sebaya, kontrol diri, serta perilaku menabung. Kuesioner final sejumlah 221 kuesioner, karena 82 responden tidak mengisi kuesioner secara lengkap.

\section{Teknik Analisis}


Untuk menguji hipotesis-hipotesis dalam penelitian ini maka teknik analisis yang digunakan adalah regresi linier berganda. Uji validitas dan reliabilitas dilakukan atas indikator-indikator empiris atas variabel-variabel yang digunakan dalam penelitian ini.

\section{Profil Responden}

Profil responden dalam penelitian ini dapat dilihat pada Tabel 2 berikut ini:

Tabel 2

Profil Responden

\begin{tabular}{|c|c|c|c|}
\hline Keterangan & Frekuensi & Persentase & Total \\
\hline Jenis Kelamin: & & & 221 \\
\hline$\overline{\text { Laki-laki }}$ & 85 & 38,5 & \\
\hline Perempuan & 136 & 61,5 & \\
\hline Umur: & & & 221 \\
\hline$\leq 18$ tahun & 23 & 10,4 & \\
\hline 19-20 tahun & 149 & 67,4 & \\
\hline 21-22 tahun & 43 & 19,5 & \\
\hline$>23$ tahun & 6 & 2,7 & \\
\hline Konsentrasi: & & & 221 \\
\hline Keuangan atau Akuntansi & 158 & 71,5 & \\
\hline Non Keuangan atau Non Akuntansi & 63 & 28,5 & \\
\hline Pendapatan: & & & 221 \\
\hline$\leq$ Rp 1 juta & 125 & 56,6 & \\
\hline Rp 1-2 juta & 89 & 40,3 & \\
\hline Rp 2-3 juta & 7 & 3,2 & \\
\hline$>$ Rp 3 juta & 0 & 0 & \\
\hline Bekerja part-time: & & & 221 \\
\hline$\overline{\mathrm{Ya}}$ & 18 & 8,1 & \\
\hline Tidak & 203 & 91,9 & \\
\hline
\end{tabular}

Sumber: Data primer yang diolah, 2015

Berdasarkan Tabel 2 di atas dapat dilihat bahwa mayoritas responden berjenis kelamin perempuan $(61,5 \%)$ dan berumur 19-20 tahun $(67,4 \%)$. Adapun konsentrasi yang diambil responden sebagian besar adalah keuangan atau akuntansi (71,5\%) dengan mayoritas pendapatan sebesar $\leq 1$ juta $(56,6 \%)$. Hanya sebagian kecil responden yang bekerja secara part time yaitu sebesar $8,1 \%$.

Walaupun prosentase jenis kelamin perempuan lebih besar jumlahnya daripada laki-laki, namun secara melek finansial tidak ada perbedaan. Demikian juga umur, pilihan konsentrasi, pendapatan dan bekerja part time atau tidak dari responden, tidak memiliki perbedaan dalam hal melek finansial. Hal tersebut dapat ditunjukkan dari asymp. sig (2 sided) menggunakan Pearson Chi Square untuk korelasi semua kategori terhadap melek finansial memiliki nilai di atas 0,05. Hal ini disebabkan kedua kategori gender memiliki tingkat pendidikan yang sama tinggi serta kemauan yang tinggi untuk mengambil tanggung jawab dalam pengelolaan keuangan pribadi. Lebih lanjut, mayoritas responden memiliki pengetahuan dasar keuangan yang relatif baik, sehingga mereka memahami perencanaan keuangan yang efektif dan efisien.

\section{Uji Validitas dan Reliabilitas}


Untuk melihat apakah indikator empirik variabel-variabel yang digunakan dalam penelitian ini valid dan reliabel maka dilakukan uji validitas dan reliabilitas. Jika nilai $\mathrm{r}$ hitung di atas 0,3 dan nilai Cronbach's Alpha lebih besar dari 0,6 maka indikator empirik dinyatakan valid dan variabel penelitian dinyatakan reliabel (Malhotra 2010).

Uji validitas dan reliabilitas dalam penelitian ini dilakukan dua kali karena ada beberapa indikator empirik yang memiliki nilai $r$ hitung di bawah 0,3 yaitu indikator pengaruh teman sebaya "sejauh saya tahu, beberapa teman saya secara teratur menabung dalam suatu rekening tabungan" dan "saya selalu membandingkan jumlah tabungan dan belanja saya dengan teman-teman saya", seperti yang terdapat pada Tabel 3 (Lampiran 1). Untuk mengatasi hal tersebut, maka dilakukan uji validitas dan reliabilitas kedua dengan menghilangkan dua indikator empirik yang memiliki nilai $r$ hitung kurang dari 0,3 .

Asumsi normalitas merupakan prasyarat untuk analisis inferensial seperti analisis regresi berganda. Jika distribusi diamati persis normal akan ada nilai nol untuk skewness dan kurtosis (Coakes, Steed, \& Ong 2010). Nilai positif bagi skewness dan kurtosis mewakili distribusi adalah positif miring dan lebih runcing dari distribusi normal. Sebaliknya, nilai negatif untuk skewness dan kurtosis menunjukkan distribusi adalah negatif miring dan datar. Skewness dan kurtosis dari semua variabel tidak boleh melebihi nilai absolut dari \pm 1 untuk memenuhi asumsi model multivariat (Sit et al., 2009). Oleh karena itu indikator empirik variabel sosialisasi orang tua "saya menghormati ketika orang tua saya memberi saya nasihat tentang bagaimana saya menggunakan uang saya" dan indikator empirik teman sebaya "saya selalu menyempatkan waktu luang saya dengan teman-teman saya" dihilangkan karena skewness dan kurtosis memiliki nilai absolut lebih dari \pm 1 . Hal tersebut dapat dilihat pada Tabel 4 (Lampiran 1).

Walaupun indikator empirik semua variabel berdistribusi normal yang ditunjukkan dari nilai skewness dan kurtosis yang tidak melebihi nilai absolut dari \pm 1 , namun secara uji reliabilitas variabel pengaruh teman sebaya memiliki cronbach's alpha yang relatif rendah yaitu 0,545. Menurut Hair, Babin, Money, dan Samouel (2003), apabila Alpha Coefficient Range <0,6 maka variabel tersebut memiliki Strength of Association yang kecil walaupun masih dinyatakan reliabel.

Uji multikolinieritas diterapkan untuk mengukur sejauh mana dua atau lebih variabel independen saling berkorelasi (Saunders, Lewis, \& Thornhill 2009). Menurut Ghozali (2011), model regresi tidak memiliki multikolinieritas jika nilai tolerance lebih besar dari 0,10 atau jika nilai VIF lebih kecil dari 10. Hasil pengujian statistik pada tabel 5 (Lampiran 2) menunjukkan bahwa model regresi linier berganda dalam penelitian ini lolos uji multikolinieritas. 


\section{ANALISIS DAN PEMBAHASAN \\ Analisis}

Tabel 6 (Lampiran 2), menunjukkan bahwa secara simultan variabel melek finansial, sosialisasi orang tua, teman sebaya, dan kontrol diri berpengaruh signifikan terhadap perilaku menabung. Hal ini dapat dilihat dari uji $\mathrm{F}$ yang memiliki tingkat signifikansi 0,00 di bawah alpha 0,05.

Berdasarkan pengujian regresi (tabel 7, Lampiran 2), diperoleh hasil bahwa variabel melek finansial, sosialisasi orang tua dan kontrol diri memiliki pengaruh yang signifikan terhadap perilaku menabung, sedangkan variabel pengaruh teman sebaya tidak memiliki pengaruh yang signifikan terhadap perilaku menabung. Hal tersebut dapat dilihat dari nilai signifikansi variabel melek finansial, sosialisasi orang tua dan kontrol diri yang di bawah alpha 0,05 yaitu 0,$019 ; 0,011$ dan 0,000 , sedangkan nilai signifikansi variabel pengaruh teman sebaya memiliki nilai signifikansi di atas alpha 0,05 yaitu 0,298.

Semakin baik melek finansial mahasiswa maka semakin baik juga perilaku menabungnya. Begitu pula dengan sosialisasi orang tua dan kontrol diri. Semakin baik sosialisasi orang tua tentang menabung dan semakin baik kontrol diri mahasiswa, maka semakin baik pula perilaku menabungnya. Tanda negatif pada koefisien regresi variabel kontrol diri dikarenakan semua indikator empirik pada variabel tersebut memiliki pernyataan negatif, sehingga bila koefisien regresinya negatif maka justru berarti sebaliknya (positif).

Berdasarkan profil responden yang diujikan terhadap variabel perilaku menabung menggunakan uji Chi-Square terlihat bahwa jenis kelamin, umur, pilihan konsentrasi (jurusan), pendapatan dan bekerja part time atau tidak, tidak memiliki asosiasi terhadap perilaku menabung. Arti dari tidak memiliki asosiasi adalah perbedaan jenis kelamin, umur, pilihan konsentrasi (jurusan), pendapatan, serta bekerja part time atau tidak, tidak memiliki hubungan dengan perilaku menabung mahasiswa. Hal tersebut dapat dilihat pada asymp. sig. (2-sided) menggunakan Pearson Chi-Square yang memiliki nilai di atas 0,05 seperti pada Tabel 8 berikut ini:

Tabel 8

Uji Chi-Square Perilaku Menabung

\begin{tabular}{|c|c|c|}
\hline $\begin{array}{l}\text { Uji Asosiasi antara Perilaku } \\
\text { Menabung dengan: }\end{array}$ & $\begin{array}{c}\text { Asymp. Sig. (2-sided) } \\
\text { menggunakan Pearson } \\
\text { Chi-Square }\end{array}$ & Keterangan \\
\hline Jenis Kelamin & 0,817 & Tidak memiliki asosiasi \\
\hline Umur & 0,483 & Tidak memiliki asosiasi \\
\hline Pilihan Konsentrasi (Jurusan) & 0,710 & Tidak memiliki asosiasi \\
\hline Pendapatan & 0,135 & Tidak memiliki asosiasi \\
\hline Bekerja Part Time atau Tidak & 0,203 & Tidak memiliki asosiasi \\
\hline
\end{tabular}

Sumber: Data primer yang diolah, 2015 


\section{Pembahasan}

Berdasarkan uji regresi pada Tabel 7, secara parsial melek finansial, sosialisasi orang tua, dan kontrol diri berpengaruh positif terhadap perilaku menabung. Hal ini berarti hipotesa pertama, kedua, dan keempat diterima. Untuk hipotesis ketiga ditolak karena secara parsial teman sebaya tidak berpengaruh signifikan terhadap perilaku menabung.

Semakin baik melek finansial mahasiswa, maka semakin baik pula perilaku menabungnya. Dari nilai rata-rata indikator empirik variabel melek finansial mahasiswa yang memiliki nilai tertinggi adalah "mahasiswa memahami dengan baik bagaimana menginvestasikan uang dan mahasiswa memahami dengan baik bagaimana mengelola hutang”. Melek finansial mahasiswa tercermin pada pemahamannya atas pengelolaan investasi dan hutang yang memengaruhi perilaku menabungnya. Untuk indikator empirik variabel melek keuangan yang memiliki nilai rata-rata terendah adalah "mahasiswa memahami dengan baik instrumen-instrumen keuangan seperti: obligasi, saham, T-bill, kontrak future, option dan lain-lain".

Semakin baik sosialisasi orang tua dalam menabung, maka semakin baik pula perilaku menabung mahasiswa. Untuk indikator empirik variabel sosialiasi orang tua yang memiliki nilai rata-rata tertinggi adalah "orang tua mahasiswa memberi contoh yang baik kepada mahasiswa saat mahasiswa melakukan manajemen keuangan dan orang tua mahasiswa bangga terhadap mahasiswa karena mahasiswa menabung". Hal ini menunjukkan bahwa keteladanan orang tua dalam mengatur keuangan mereka memberi dampak positif bagi mahasiswa untuk memiliki kegemaran menabung. Jenis kelamin dan usia mahasiswa tidak membedakan perilaku menabung mereka, asalkan orang tua memberi contoh yang baik dalam pengelolaan keuangan dan memberi apresiasi positif kepada responden saat mereka mengambil keputusan untuk menabung. Adapun indikator empirik variabel sosialisasi orang tua yang memiliki nilai rata-rata terendah adalah "mahasiswa selalu membicarakan manajemen keuangannya kepada orang tua".

Pengaruh teman sebaya tidak memiliki efek yang siginifikan terhadap perilaku menabung mahasiswa. Hal ini yang membedakan penelitian ini dari hasil penelitianpenelitian sebelumnya. Indikator empirik yang dikategorikan valid dalam variabel ini adalah "mahasiswa selalu mendiskusikan masalah-masalah manajemen keuangan, khususnya menabung dengan teman-temannya dan mahasiswa selalu melibatkan temantemannya dalam aktivitas belanja". Penyebab variabel pengaruh teman sebaya mahasiswa tidak memiliki efek yang signifikan adalah kurangnya kebiasaan diskusi masalah-masalah manajemen keuangan di kalangan mahasiswa. Selain itu, ada kecenderungan perilaku individualistik para mahasiswa dalam aktivitas berbelanja meskipun secara uji asosiasi tidak ada perbedaan antara mahasiswa yang bekerja part time atau tidak dalam perilaku menabungnya.

Namun secara simultan, pengaruh teman sebaya memiliki efek signifikan terhadap perilaku menabung. Responden dalam penelitian ini dapat dikategorikan usia 
remaja, karena mayoritas responden yang berusia sekitar 12-21 tahun sebesar 77,8\% (Monks, Knoers, \& Haditomo 2002). Pada usia ini, pilihan-pilihan konsumsi para remaja sangat dipengaruhi aktivitas-aktivitas yang ditekuninya, teman-teman dan penampilan generasi itu (Kasali 2011). Pengaruh teman sebaya yang sifatnya simultan menjadikan pengaruh teman sebaya berkolaborasi dengan sosialisasi orang tua sebagai norma subyektif dan kontrol perilaku di tengah di masyarakat. Menurut Steinberg (2002), pada umumnya remaja menghabiskan uangnya untuk berbelanja pakaian, makan, kosmetik, namun mereka juga tidak lupa menyisihkan uangnya untuk ditabung. Di sini peran orang tua dalam mendidik anak usia remaja menjadi faktor penyeimbang antara gaya hidup berbelanja dan perilaku hemat efektif yang diperoleh dari teladan menabung orang tua. Di samping itu, kolaborasi dengan faktor kontrol diri dan melek finansial mahasiswa menjadikan mereka bisa memiliki strategi bertahan dari sifat boros yang muncul dari pengaruh teman sebaya.

Variabel kontrol diri berpengaruh positif signifikan terhadap perilaku menabung. Hal ini berarti semakin baik kontrol diri mahasiswa, maka semakin baik pula perilaku menabungnya. Indikator empirik kontrol diri yang memiliki nilai rata-rata tertinggi adalah "mahasiswa mau menabung karena berfikir itu mudah dan mahasiswa menikmati membelanjakan uang untuk sesuatu yang penting”. Di sini terlihat kontrol diri responden dipicu oleh adanya persepsi bahwa menabung itu tidak sulit dan mereka telah memiliki kesadaran adanya skala prioritas dalam membelanjakan uang mereka. Untuk indikator empirik variabel kontrol diri yang memiliki nilai rata-rata terendah adalah "mahasiswa lebih fokus dalam keputusan jangka pendek daripada jangka panjang”.

Untuk indikator empirik variabel perilaku menabung yang memiliki nilai rata-rata tertinggi adalah sebagai berikut: "mahasiswa sering membandingkan harga sebelum melakukan pembelian untuk kepentingan menabung dan mahasiswa menabung untuk mencapai tujuan-tujuan tertentu”. Hal ini menunjukkan bahwa yang menggerakkan responden untuk menabung adalah capaian tujuan yang telah ditetapkan mahasiswa. Responden juga melakukan perbandingan harga saat melakukan kegiatan belanja, artinya mahasiswa membeli dengan suatu perencanaan keuangan yang baik. Adapun indikator empirik variabel perilaku menabung yang memiliki nilai terendah adalah "mahasiswa menyisihkan uang secara teratur untuk masa depan”.

\section{SIMPULAN, KETERBATASAN DAN SARAN}

\section{Simpulan}

Secara parsial, melek finansial, sosialisasi orang tua dan kontrol diri berpengaruh positif signifikan terhadap perilaku menabung, sedangkan variabel pengaruh teman sebaya tidak berpengaruh signifikan terhadap perilaku menabung. Melek finansial mahasiswa tercermin pada pemahamannya atas pengelolaan investasi dan hutang. Hasil penelitian ini juga menunjukkan orang tua yang memberi teladan dalam pengelolaan keuangan dan apresiasi positif kepada mahasiswa saat mereka mengambil keputusan 
untuk menabung dapat memengaruhi perilaku mahasiswa dalam menabung. Variabel kontrol diri secara parsial juga berpengaruh terhadap perilaku menabung mahasiswa. Hal ini dipicu oleh adanya persepsi bahwa menabung itu tidak sulit dan mahasiswa telah memiliki kesadaran adanya skala prioritas dalam membelanjakan uang mereka. Secara simultan, variabel melek finansial, sosialisasi orang tua, teman sebaya dan kontrol diri berpengaruh signifikan terhadap perilaku menabung.

\section{Implikasi Teoretis}

Hasil penelitian ini mendukung penelitian Sabri dan MacDonald (2010) serta Ming Thung et al. (2012) yang juga menunjukkan bahwa melek finansial memiliki pengaruh positif signifikan terhadap perilaku menabung mahasiswa. Penelitian tersebut menunjukkan bahwa mahasiswa yang memiliki pengetahuan yang besar pada keuangan pribadi cenderung memiliki perilaku hemat efektif. Tingkat literasi keuangan mahasiswa dapat meliputi pemahaman atas jasa perbankan, asuransi, pegadaian, lembaga pembiayaan, dana pensiun, serta pasar modal. Hal ini penting guna meningkatkan tingkat pemanfaatan produk-produk keuangan tersebut.

Selain variabel melek finansial, variabel lain yang berpengaruh signifikan terhadap perilaku menabung adalah sosialisasi orang tua. Hal ini didukung oleh penelitian Mischel (1961) yang membuktikan bahwa orang tua dapat memengaruhi perilaku menabung anak-anak mereka. Penelitian Cude et al. (2006) menemukan bahwa orang tua memainkan peran sentral dalam sosialisasi keuangan anak-anak mereka. Seperti halnya penelitian Cude et al. (2006), penelitian Furnham (1999) dan Otto (2009) juga menyatakan bahwa perilaku orang dewasa muda terkait hubungan mereka dengan orang tua.

Penelitian Wahana (2014) menunjukkan salah satu variabel yang memengaruhi probabilitas menabung adalah kontrol diri. Beberapa penelitian terdahulu (Ainslie 1975; Strotz 1955; Warneryd 1999; Wood 1998) juga menyatakan bahwa kontrol diri memengaruhi keputusan ekonomi dan keputusan-keputusan lainnya. Begitu pula penelitian Webley dan Nyhus (2006) memiliki hasil yang sama. Oleh karena itu dapat dikatakan hasil penelitian ini yaitu kontrol diri berpengaruh positif signifikan terhadap perilaku menabung telah mendukung hasil penelitian-penelitian terdahulu.

Hasil penelitian ini memiliki perbedaan dengan penelitian-penelitian sebelumnya. Variabel pengaruh teman sebaya tidak berpengaruh signifikan terhadap perilaku menabung. Hal ini bertentangan dengan hasil penelitian Youniss dan Haynie (1992) dan Ming Thung et al. (2012). Youniss dan Haynie (1992) menekankan bahwa persahabatan menjadi hal yang penting bagi perkembangan psikologis dan kejiwaan para remaja. Interaksi antar rekan menjadi alat terapi bagi remaja bermasalah. Namun fenomena yang terjadi dalam penelitian ini terlihat adanya perbedaan perkembangan kedewasaan para remaja dengan memperhitungkan konteks budaya dan perubahan historis antara pria dan wanita. Rice (1992) berpendapat perilaku mereka yang cenderung ingin tampil beda dapat menjadi pencetus konflik dalam penyesuaian diri dengan kelompok mereka. 
Dalam penelitian Ming Thung et al. (2012) adalah mayoritas responden memiliki umur 21-22 tahun dan >23 tahun sebesar 82 persen, sementara penelitian ini untuk kategori umur 21-22 tahun dan >23 tahun hanya sebesar 22,2 persen, artinya responden penelitian Thung et al. (2012) lebih banyak masuk kriteria dewasa, sementara responden penelitian ini termasuk dalam usia remaja. Menurut Kasali (2011), remaja cenderung ingin memberontak melawan ketentuan-ketentuan sosial yang baku. Hal tersebut terjadi karena adanya perubahan fisik dan psikis remaja sehingga para remaja menjadi berperilaku impulsif (Hurlock 1997). Oleh karena itu dalam penelitian ini secara parsial pengaruh teman sebaya tidak memiliki efek yang signifikan terhadap perilaku menabung.

\section{Implikasi Terapan}

Indikator empirik variabel melek keuangan yang memiliki nilai terendah adalah "mahasiswa memahami dengan baik instrumen-instrumen keuangan seperti: obligasi, saham, T-bill, kontrak future, option dan lain-lain". Untuk itu pihak FEB UKSW disarankan dapat secara rutin mengadakan seminar atau workshop tentang pasar uang dan pasar modal beserta dengan sertifikasinya, sehingga mahasiswa dapat melakukan investasi secara pintar. Adapun indikator empirik variabel sosialisasi orang tua yang memiliki nilai rata-rata terendah adalah "mahasiswa selalu membicarakan manajemen keuangannya kepada orang tua". Saran bagi mahasiswa untuk hal ini adalah karena mahasiswa masih di bawah tanggung jawab orang tua, maka sebaiknya mahasiswa membudayakan sharing tentang aktivitas ekonominya dengan orang tua untuk mencegah terjadinya aliran kas yang defisit.

Untuk indikator empirik variabel kontrol diri yang memiliki nilai rata-rata terendah adalah "mahasiswa lebih fokus dalam keputusan jangka pendek daripada jangka panjang", sehingga disarankan mahasiswa FEB UKSW melakukan manajemen prioritas berdasarkan kebutuhan bukan keinginan. Adapun indikator empirik variabel perilaku menabung yang memiliki nilai terendah adalah "mahasiswa menyisihkan uang secara teratur untuk masa depan”. Saran untuk hal tersebut adalah mahasiswa melakukan evaluasi dan strategi yang tepat atas kegiatan pembelanjaannya berdasarkan prinsip-prinsip keuangan yang benar.

\section{DAFTAR PUSTAKA}

Ainslie, George. 1975. "Specious reward: A behavioral theory of impulsiveness and impulse control." Psychological Bulletin 82 (4): 463-96. https://doi.org/10.1037/h0076860.

Ajzen, I, dan M Fishbein. 1980. Understanding attitudes and predicting social behavior. EnglewoodCliffs NY Prentice Hall. https://doi.org/Z.

Anthes, W. L. 2000. "Frozen in the headlights: The dynamics of women and money." Journal of Financial Planning 13 (9): 130-42.

Assael, Henry. 1998. Customer behavior and marketing action. 6ed. Ohio: South Western 
College Publishing.

Athukorala, Prema Chandra, dan Kunal Sen. 2004. "The determinants of private saving in India." World Development 32 (3): 491-503. https://doi.org/10.1016/j.worlddev.2003.07.008.

Baumeister, Roy F. 2002. "Yielding to Temptation: Self-Control Failure, Impulsive Purchasing, and Consumer Behavior." Journal of Consumer Research 28 (4): 670-76. https://doi.org/10.1086/338209.

Browning, Martin, dan Annamaria Lusardi. 1996. "Household saving: Micro theories and mirco facts." Journal of Economic Literature 34 (4): 1797-1855.

Coakes, Sheridan J., Lyndall Steed, dan Clara Ong. 2010. SPSS : analysis without anguish : version 17.0 for windows. Australia: John Wiley \& Sons.

Cook, A. J., G. N. Kerr, dan K. Moore. 2002. "Attitudes and intentions towards purchasing GM food.” Journal of Economic Psychology 23 (5): 557-72. https://doi.org/10.1016/S0167-4870(02)00117-4.

Cude, Brenda, Frances Lawrence, Angela Lyons, Kaci Metzger, Emily LeJeune, Loren Marks, dan Krisanna Machtmes. 2006. "College Students and Financial Literacy: What They Know and What We Need to Learn." Eastern Family Economics and Resource Management Association, 102-9.

Delafrooz, Narges, dan Laily Hj Paim. 2011. "Determinants of saving behavior and financial problem among employees in Malaysia." Australian Journal of Basic and Applied Sciences 5 (7): 222-28.

Domar, Evsey D. 1946. "Capital expansion, rate of growth, and employment." Econometrica 14 (2): 137-47. https://doi.org/10.2307/1905364.

Erskine, Michele, Cheryl Kier, Ambrose Leung, dan Robert Sproule. 2006. "Peer crowds, work experience, and financial saving behaviour of young Canadians." Journal $\begin{array}{lllll}\text { of } & \text { Economic } & \text { Psychology } & 27 & \text { (2): }\end{array}$ https://doi.org/10.1016/j.joep.2005.05.005.

Esenvalde, Inese. 2011. "Psychological predictors of savings behavior: Contrasting the impact of optimism and burnout on self-control, achievement motivation and savings behavior." ProQuest Dissertations and Theses.

Fishbein, M., dan I. Ajzen. 1975. Belief, Attitude, Intention and Behaviour: An Introduction to Theory and Research. Addison-Wesley Publishing Company. https://doi.org/10.2307/2065853.

Furnham, Adrian. 1999. "The saving and spending habits of young people." Journal of Economic Psychology 20 (6): 677-97. https://doi.org/10.1016/S01674870(99)00030-6.

Garman, E. T., dan R. E. Forgue. 2006. Personal Finance. Boston: Houghton Mifflin Co,. 
Ghozali, Imam. 2011. Aplikasi Analisis Multivariate dengan Program IBM SPSS 19. Semarang: Badan Penerbit Universitas Diponegoro.

Hair, J. F., Jr. B. Babin, A. H. Money, dan P. Samouel. 2003. Essential of Business Research Methods. United States of America: John Wiley \& Sons.

Harrod, R. F. 1939. “An Essay in Dynamic Theory.” The Economic Journal 49 (193): 14-33. https://doi.org/10.2307/2225181.

Hurlock, E. B. 1997. Psikologi perkembangan: Suatu pendekatan sepanjang rentan kehidupan. Jakarta: Erlangga.

Inkeles, A. 1969. Social structure and socialisation. USA: Rand McNally \& Company.

Kasali, R. 2011. Membidik Pasar Indonesia: Segmenting, Targeting, Positioning. Jakarta: PT. Gramedia Pustaka Utama.

Keynes, J. M. 1936. The General Theory of Employment, Interest and Money. Harcourt: Brace and World.

Lim, C. S., B. K. Sia, dan G. J. Gan. 2011. "The analysis of psychological factors affecting savers in Malaysia." Middle Eastern Finance and Economics 12 (12): $77-85$.

Lusardi, Annamaria. 2005. "Financial education and the saving behavior of african american and hispanic households."

- 2008. "Household saving behavior: The role financial literacy, information and financial education programs." NBER Working Paper Series, no. 13824. https://doi.org/10.3386/w13824.

Malhotra, Naresh K. 2010. Marketing research: An applied orientation. Pearson. 6ed. United States of America.

Mankiw, N. G. 2007. Macroeconomics. 6ed. New York: Worth Publisher.

Mathieson, Kieran. 1991. "Predicting user intentions: Comparing the technology acceptance model with the theory of planned behavior." Information Systems Research 2 (3): 173-91. https://doi.org/10.1287/isre.2.3.173.

Ming Thung, Chai, Chia Ying Kai, Fong Sheng Nie, Lew Wan Chiun, dan Tan Chang Tsen. 2012. "Determinants of saving behaviour among the university students in Malaysia." Universiti Tunku Abdul Rahman, no. 109.

Mischel, Walter. 1961. "Father-absence and delay of gratification: Cross-cultural comparisons." The Journal of Abnormal and Social Psychology 63 (1): 116-24. https://doi.org/10.1037/h0046877.

Monks, F. J., A.M.P Knoers, dan Siti Rahayu Haditomo. 2002. Psikologi perkembangan. Yogyakarta: Gadjah Mada University Press.

Nyhus, Ellen Katrine. 2002. "Psychological Determinants of Household Saving 
Behavior." Norwegian School of Economics and Business Administration, Bergen.

Otto, Annette Michaela Cosima. 2009. "The Economic Psychology of Adolescent Saving." Exeter: University of Exeter.

Pavlou, Paul A, dan Mendel Fygenson. 2006. "Understanding and predicting electronic commerce adoption: An extension of the theory of planned behavior." MIS Quarterly 30 (1): 115-43. https://doi.org/10.2307/25148720.

Pellino, T. A. 1997. "Relationships between patient attitudes, subjective norms, perceived control, and analgesic use following elective orthopedic surgery." Research in nursing \& health 20 (2): 97-105.

Rice, F. Philip. 1992. The adolescent: development, relationships, and culture. 7ed. Boston: Allyn and Bacon.

Rustow, D. A. 1967. A World of Nations; Problems of Political Modernization. Diedit oleh The Brookings Instituion. Washingtom.

Sabri, M.F., MacDonald, M., Masud, Jariah, Paim, L. Hira, T.K., \& Othman M.A. 2008. "Financial behavior and problems among college students in Malaysia: Research and education implication." Consumer Interests Annual 54: 166-70.

Sabri, Mohamad Fazli, dan Maurice MacDonald. 2010. "Savings Behavior and Financial Problems among College Students: The Role of Financial Literacy in Malaysia | Sabri | Cross-cultural Communication." Crosscultural Communication 6 (3): 103-10. https://doi.org/10.3968/j.ccc.1923670020100603.009.

Saunders, M., P. Lewis, dan A. Thornhill. 2009. Research methods for business students. Business. $\quad$ 4ed. Harlow, England: Prentice Hall. https://doi.org/10.1017/CBO9781107415324.004.

Sit, Wen Yi, Keng Boon Ooi, Binshan Lin, dan Alain Yee Loong Chong. 2009. "TQM and customer satisfaction in Malaysia's service sector." Industrial Management and Data Systems 109 (7): 957-75. https://doi.org/10.1108/02635570910982300.

Steinberg, L. 2002. Adolescence. 6ed. New York: McGraw Hill Companies Inc.

Strotz, R. H. 1955. "Myopia and inconsistency in dynamic utility maximization." The Review of Economic Studies 23 (3): 159-73. https://doi.org/10.2307/2295722.

Susetyo, D. 2011. “Analisis pengaruh tingkat investasi, aglomerasi, tenaga kerja, dan indeks pembangunan manusia terhadap pertumbuhan ekonomi kabupaten/kota di jawa tengah." Fakultas Ekonomi Universitas Diponegoro Semarang.

Todaro, M. P. 1983. Ekonomi Pembangunan di Dunia Ketiga. Jakarta: Penerbit Balai Aksara.

Tooth, R. J. 2006. Relative Position and Saving Behaviour. Sydney: The University of New South Wales. 
Wahana, A. 2014. “Analisis faktor-faktor yang mempengaruhi perilaku mahasiswa dalam menabung (studi kasus mahasiswa strata satu fakultas ekonomika dan bisnis universitas diponegoro tembalang).” Program Sarjana Fakultas Ekonomika dan Bisnis Universitas Diponegoro.

Warneryd, K. E. 1999. The Psychology of Saving: A Study on Economic Psychology. UK: Edward Elgar.

Webley, Paul, dan Ellen K. Nyhus. 2006. 'Parents' influence on children's future orientation and saving." Journal of Economic Psychology 27 (1): 140-64. https://doi.org/10.1016/j.joep.2005.06.016.

Wiethoff, Carolyn. 2004. "Motivation to learn and diversity training: Application of the theory of planned behavior." Human Resource Development Quarterly 15 (3): 263-78. https://doi.org/10.1002/hrdq.1103.

Wood, Michael. 1998. "Socio-economic status, delay of gratification, and impulse buying." Journal of Economic Psychology 19 (3): 295-320. https://doi.org/10.1016/S0167-4870(98)00009-9.

Youniss, James, dan Denise L Haynie. 1992. "Friendship in adolescence." Developmental and Behavioral Pediatrics 13 (1): 59-66. https://doi.org/10.1097/00004703199202000-00013. 


\section{LAMPIRAN 1}

Tabel 3

Uji Validitas dan Reliabilitas 1

\begin{tabular}{|c|c|c|c|c|c|}
\hline Indikator Empirik & Mean & Skewness & Kurtosis & $\begin{array}{l}\text { Corrected } \\
\text { Item-Total } \\
\text { Correlation }\end{array}$ & $\begin{array}{l}\text { Cronbach's } \\
\quad \text { Alpha }\end{array}$ \\
\hline Melek Finansial: & & & & & 0,712 \\
\hline $\begin{array}{l}\text { Saya memahami dengan baik } \\
\text { bagaimana menginvestasikan uang } \\
\text { saya. }\end{array}$ & 3,35 & $-0,384$ & 0,319 & 0,608 & \\
\hline $\begin{array}{l}\text { Saya memahami dengan baik } \\
\text { bagaimana mengelola hutang saya. }\end{array}$ & 3,75 & $-0,671$ & 0,716 & 0,415 & \\
\hline $\begin{array}{l}\text { Saya memahami dengan baik tentang } \\
\text { kebutuhan keuangan saya sampai } \\
\text { masa pensiun tiba. }\end{array}$ & 3,04 & $-0,286$ & $-0,172$ & 0,387 & \\
\hline $\begin{array}{l}\text { Saya memahami dengan baik } \\
\text { instrumen-instrumen } \\
\text { seperti: obligasi, saham, T-bill, } \\
\text { kontrak future, option, dll. }\end{array}$ & 2,67 & $-0,013$ & $-0,285$ & 0,263 & \\
\hline Sosialisasi Orang Tua: & & & & & 0,779 \\
\hline $\begin{array}{l}\text { Orang tua saya memberi contoh yang } \\
\text { baik kepada saya saat saya melakukan } \\
\text { manajemen keuangan. }\end{array}$ & 4,07 & $-1,250$ & 1,602 & 0,594 & \\
\hline $\begin{array}{l}\text { Saya selalu membicarakan } \\
\text { manajemen keuangan saya kepada } \\
\text { orang tua saya. }\end{array}$ & 3,53 & $-0,493$ & $-0,555$ & 0,563 & \\
\hline $\begin{array}{l}\text { Saya merasa baik saat orang tua saya } \\
\text { mengawasi pengeluaran saya. }\end{array}$ & 3,62 & $-0,640$ & 0,055 & 0,588 & \\
\hline $\begin{array}{l}\text { Saya merasa baik saat saya } \\
\text { menanyakan kepada orang tua saya } \\
\text { tentang bagaimana saya } \\
\text { membelanjakan uang saya sehingga } \\
\text { menolong saya untuk berhemat. }\end{array}$ & 3,67 & $-0,766$ & 0,559 & 0,58 & \\
\hline $\begin{array}{l}\text { Orang tua saya bangga terhadap saya } \\
\text { karena saya menabung. }\end{array}$ & 3,74 & $-0,493$ & 0,017 & 0,383 & \\
\hline $\begin{array}{l}\text { Saya menghormati ketika orang tua } \\
\text { saya memberi saya nasihat tentang } \\
\text { bagaimana saya menggunakan uang } \\
\text { saya. }\end{array}$ & 4,36 & $-1,728$ & 4,915 & 0,473 & \\
\hline
\end{tabular}




\begin{tabular}{|c|c|c|c|c|c|}
\hline Indikator Empirik & Mean & Skewness & Kurtosis & $\begin{array}{l}\text { Corrected } \\
\text { Item-Total } \\
\text { Correlation }\end{array}$ & $\begin{array}{l}\text { Cronbach's } \\
\quad \text { Alpha }\end{array}$ \\
\hline $\begin{array}{l}\text { Saya menabung karena saya tidak } \\
\text { berfikir orang tua saya mengijinkan } \\
\text { saya membeli sesuatu jika saya tidak } \\
\text { benar-benar memerlukan walaupun } \\
\text { menyukainya. }\end{array}$ & 3,64 & $-0,347$ & $-0,494$ & 0,327 & \\
\hline $\begin{array}{l}\text { Menabung adalah sesuatu yang saya } \\
\text { kerjakan secara teratur karena orang } \\
\text { tua saya menginginkan saya berhemat } \\
\text { sekecil apapun. }\end{array}$ & 3,61 & $-0,493$ & $-0,335$ & 0,376 & \\
\hline Teman Sebaya: & & & & & 0,545 \\
\hline $\begin{array}{l}\text { Sejauh saya tahu, beberapa teman } \\
\text { saya secara teratur menabung dalam } \\
\text { suatu rekening tabungan. }\end{array}$ & 3,1 & $-0,180$ & $-0,338$ & 0,17 & \\
\hline $\begin{array}{l}\text { Saya selalu mendiskusikan masalah- } \\
\text { masalah manajemen keuangan, } \\
\text { khususnya menabung dengan teman- } \\
\text { teman saya. }\end{array}$ & 2,65 & 0,255 & $-0,284$ & 0,475 & \\
\hline $\begin{array}{l}\text { Saya selalu membandingkan jumlah } \\
\text { tabungan dan belanja saya dengan } \\
\text { teman-teman saya. }\end{array}$ & 2,29 & 0,561 & $-0,380$ & 0,245 & \\
\hline $\begin{array}{l}\text { Saya selalu menyempatkan waktu } \\
\text { luang saya dengan teman-teman saya. }\end{array}$ & 4,04 & $-1,248$ & 2,746 & 0,271 & \\
\hline $\begin{array}{l}\text { Saya selalu melibatkan teman-teman } \\
\text { saya dalam aktivitas belanja saya. }\end{array}$ & 2,98 & 0,195 & $-0,490$ & 0,404 & \\
\hline Kontrol Diri: & & & & & 0,894 \\
\hline $\begin{array}{l}\text { Saya tidak menabung karena saya } \\
\text { berfikir itu terlalu sulit. }\end{array}$ & 2,05 & 0,807 & $-0,107$ & 0,591 & \\
\hline $\begin{array}{l}\text { Saya menikmati membelanjakan uang } \\
\text { saya untuk sesuatu yang tidak penting. }\end{array}$ & 2,12 & 0,621 & $-0,179$ & 0,633 & \\
\hline $\begin{array}{l}\text { Ketika saya memperoleh uang, saya } \\
\text { selalu membelanjakan itu secara } \\
\text { mendadak (antara satu atau dua hari). }\end{array}$ & 2,31 & 0,487 & $-0,660$ & 0,694 & \\
\hline $\begin{array}{l}\text { "Saya melihat, saya suka, dan saya } \\
\text { membeli sesuatu" mendeskripsikan } \\
\text { tentang saya. }\end{array}$ & 2,65 & 0,432 & $-0,649$ & 0,642 & \\
\hline $\begin{array}{l}\text { "Lakukan saja" mendeskripsikan cara } \\
\text { saya membeli sesuatu. }\end{array}$ & 2,34 & 0,735 & 0,221 & 0,704 & \\
\hline
\end{tabular}




\begin{tabular}{|c|c|c|c|c|c|}
\hline Indikator Empirik & Mean & Skewness & Kurtosis & $\begin{array}{l}\text { Corrected } \\
\text { Item-Total } \\
\text { Correlation }\end{array}$ & $\begin{array}{l}\text { Cronbach's } \\
\text { Alpha }\end{array}$ \\
\hline $\begin{array}{l}\text { "Beli sekarang, pikir itu kemudian" } \\
\text { mendeskripsikan tentang saya. }\end{array}$ & 2,2 & 0,809 & 0,092 & 0,651 & \\
\hline $\begin{array}{l}\text { Saya dengan mudah tertarik dengan } \\
\text { iming-iming. }\end{array}$ & 2,26 & 0,743 & 0,150 & 0,558 & \\
\hline $\begin{array}{l}\text { Saya selalu gagal mengendalikan diri } \\
\text { saya dalam membelanjakan uang } \\
\text { sava. }\end{array}$ & 2,53 & 0,471 & $-0,311$ & 0,679 & \\
\hline $\begin{array}{l}\text { Ketika saya menentukan tujuan untuk } \\
\text { menabung bagi diri saya sendiri, saya } \\
\text { jarang mencapainya. }\end{array}$ & 2,7 & 0,233 & $-0,301$ & 0,629 & \\
\hline $\begin{array}{l}\text { Saya lebih fokus dengan apa yang } \\
\text { terjadi kepada saya dalam jangka } \\
\text { pendek daripada jangka panjang. }\end{array}$ & 2,67 & 0,116 & $-0,678$ & 0,58 & \\
\hline Perilaku Menabung: & & & & & 0,783 \\
\hline $\begin{array}{l}\text { Saya menyisihkan uang saya secara } \\
\text { teratur untuk masa depan. }\end{array}$ & 3,34 & $-0,182$ & $-0,241$ & 0,487 & \\
\hline $\begin{array}{l}\text { Untuk kepentingan menabung, saya } \\
\text { sering membandingkan harga } \\
\text { sebelum saya melakukan pembelian. }\end{array}$ & 3,81 & $-0,363$ & $-0,269$ & 0,49 & \\
\hline $\begin{array}{l}\text { Untuk kepentingan menabung, saya } \\
\text { sering mempertimbangkan apakah } \\
\text { kebutuhan utama saya sebelum saya } \\
\text { melakukan pembelian. }\end{array}$ & 3,79 & $-0,462$ & 0,199 & 0,58 & \\
\hline $\begin{array}{l}\text { Untuk kepentingan menabung, saya } \\
\text { selalu hati-hati dalam melakukan } \\
\text { penganggaran secara bulanan. }\end{array}$ & 3,52 & $-0,245$ & $-0,290$ & 0,558 & \\
\hline $\begin{array}{l}\text { Saya selalu memiliki uang yang } \\
\text { diperlukan untuk acara-acara yang } \\
\text { sifatnya mendadak. }\end{array}$ & 3,51 & $-0,179$ & $-0,471$ & 0,484 & \\
\hline $\begin{array}{l}\text { Untuk kepentingan menabung, saya } \\
\text { berencana mengurangi pengeluaran } \\
\text { saya. }\end{array}$ & 3,76 & $-0,463$ & 0,140 & 0,536 & \\
\hline $\begin{array}{l}\text { Saya menabung untuk mencapai } \\
\text { tujuan-tujuan tertentu. }\end{array}$ & 4,08 & $-0,591$ & $-0,004$ & 0,45 & \\
\hline $\begin{array}{l}\text { Saya menabung sampai akhir } \\
\text { semester saya. }\end{array}$ & 3,34 & $-0,264$ & $-0,573$ & 0,365 & \\
\hline
\end{tabular}

Sumber: Data primer yang diolah, 2015 
Tabel 4

Uji Validitas dan Reliabilitas 2

\begin{tabular}{|c|c|c|c|c|c|}
\hline Indikator Empirik & Mean & Skewness & Kurtosis & $\begin{array}{c}\text { Corrected } \\
\text { Item-Total } \\
\text { Correlation }\end{array}$ & $\begin{array}{l}\text { Cronbach's } \\
\text { Alpha }\end{array}$ \\
\hline Melek Finansial: & & & & & 0,712 \\
\hline $\begin{array}{l}\text { Saya memahami dengan baik } \\
\text { bagaimana menginvestasikan uang } \\
\text { saya. }\end{array}$ & 3,35 & $-0,384$ & 0,319 & 0,608 & \\
\hline $\begin{array}{l}\text { Saya memahami dengan baik } \\
\text { bagaimana mengelola hutang saya. }\end{array}$ & 3,75 & $-0,671$ & 0,716 & 0,415 & \\
\hline $\begin{array}{l}\text { Saya memahami dengan baik } \\
\text { tentang kebutuhan keuangan saya } \\
\text { sampai masa pensiun tiba. }\end{array}$ & 3,04 & $-0,286$ & $-0,172$ & 0,387 & \\
\hline $\begin{array}{l}\text { Saya memahami dengan baik } \\
\text { instrumen-instrumen keuangan } \\
\text { seperti: obligasi, saham, T-bill, } \\
\text { kontrak future, option, dll. }\end{array}$ & 2,67 & $-0,013$ & $-0,285$ & 0,263 & \\
\hline Sosialisasi Orang Tua: & & & & & 0,779 \\
\hline $\begin{array}{l}\text { Orang tua saya memberi contoh } \\
\text { yang baik kepada saya saat saya } \\
\text { melakukan manajemen keuangan. }\end{array}$ & 4,07 & $-1,250$ & 1,602 & 0,594 & \\
\hline $\begin{array}{l}\text { Saya selalu membicarakan } \\
\text { manajemen keuangan saya kepada } \\
\text { orang tua saya. }\end{array}$ & 3,53 & $-0,493$ & $-0,555$ & 0,563 & \\
\hline $\begin{array}{l}\text { Saya merasa baik saat orang tua } \\
\text { saya mengawasi pengeluaran saya. }\end{array}$ & 3,62 & $-0,640$ & 0,055 & 0,588 & \\
\hline $\begin{array}{l}\text { Saya merasa baik saat saya } \\
\text { menanyakan kepada orang tua saya } \\
\text { tentang bagaimana saya } \\
\text { membelanjakan uang saya sehingga } \\
\text { menolong saya untuk berhemat. }\end{array}$ & 3,67 & $-0,766$ & 0,559 & 0,58 & \\
\hline $\begin{array}{l}\text { Orang tua saya bangga terhadap } \\
\text { saya karena saya menabung. }\end{array}$ & 3,74 & $-0,493$ & 0,017 & 0,383 & \\
\hline $\begin{array}{l}\text { Saya menabung karena saya tidak } \\
\text { berfikir orang tua saya mengijinkan } \\
\text { saya membeli sesuatu jika saya } \\
\text { tidak benar-benar memerlukan } \\
\text { walaupun menyukainya. }\end{array}$ & 3,64 & $-0,347$ & $-0,494$ & 0,327 & \\
\hline $\begin{array}{l}\text { Menabung adalah sesuatu yang } \\
\text { saya kerjakan secara teratur karena } \\
\text { orang tua saya menginginkan saya } \\
\text { berhemat sekecil apapun. }\end{array}$ & 3,61 & $-0,493$ & $-0,335$ & 0,376 & \\
\hline
\end{tabular}




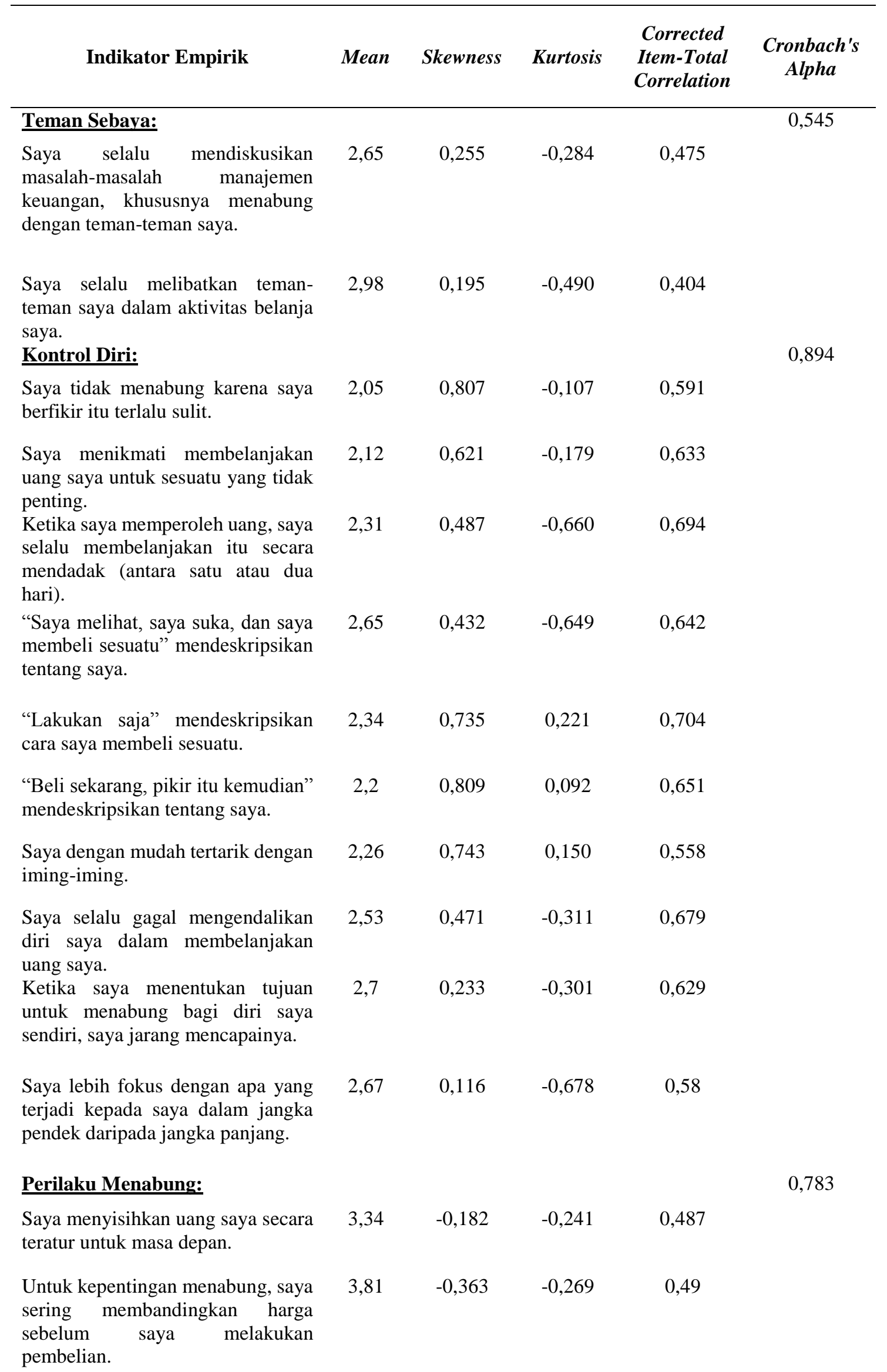




\begin{tabular}{|c|c|c|c|c|c|}
\hline Indikator Empirik & Mean & Skewness & Kurtosis & $\begin{array}{l}\text { Corrected } \\
\text { Item-Total } \\
\text { Correlation }\end{array}$ & $\begin{array}{l}\text { Cronbach's } \\
\quad \text { Alpha }\end{array}$ \\
\hline $\begin{array}{l}\text { Untuk kepentingan menabung, saya } \\
\text { sering mempertimbangkan apakah } \\
\text { kebutuhan utama saya sebelum saya } \\
\text { melakukan pembelian. }\end{array}$ & 3,79 & $-0,462$ & 0,199 & 0,58 & \\
\hline $\begin{array}{l}\text { Untuk kepentingan menabung, saya } \\
\text { selalu hati-hati dalam melakukan } \\
\text { penganggaran secara bulanan. }\end{array}$ & 3,52 & $-0,245$ & $-0,290$ & 0,558 & \\
\hline $\begin{array}{l}\text { Saya selalu memiliki uang yang } \\
\text { diperlukan untuk acara-acara yang } \\
\text { sifatnya mendadak. }\end{array}$ & 3,51 & $-0,179$ & $-0,471$ & 0,484 & \\
\hline $\begin{array}{l}\text { Untuk kepentingan menabung, saya } \\
\text { berencana mengurangi pengeluaran } \\
\text { saya. }\end{array}$ & 3,76 & $-0,463$ & 0,140 & 0,536 & \\
\hline $\begin{array}{l}\text { Saya menabung untuk mencapai } \\
\text { tujuan-tujuan tertentu. }\end{array}$ & 4,08 & $-0,591$ & $-0,004$ & 0,45 & \\
\hline $\begin{array}{l}\text { Saya menabung sampai akhir } \\
\text { semester saya. }\end{array}$ & 3,34 & $-0,264$ & $-0,573$ & 0,365 & \\
\hline
\end{tabular}

Sumber: Data primer yang diolah, 2015 


\section{LAMPIRAN 2}

Tabel 5

Uji Multikolinieritas

\begin{tabular}{|c|c|c|}
\hline \multirow{2}{*}{ Model } & \multicolumn{2}{|c|}{ Collinearity Statistics } \\
\hline & Tolerance & VIF \\
\hline \multicolumn{3}{|l|}{ (Constant) } \\
\hline Melek Finansial & 0,863 & 1,159 \\
\hline Sosialisasi Orang Tua & 0,840 & 1,191 \\
\hline Teman Sebaya & 0,925 & 1,082 \\
\hline Kontrol Diri & 0,918 & 1,090 \\
\hline
\end{tabular}

Sumber: Data primer yang diolah, 2015

\begin{tabular}{rlrrrrr}
\multicolumn{7}{c}{ Tabel 6 } \\
Uji F \\
\hline \multirow{2}{*}{ Model } & Sum of Squares & df & Mean Square & \multicolumn{1}{c}{ F } & Sig. \\
\hline \multirow{2}{*}{1} & Regression & 8,762 & 4 & 2,191 & 9,976 & $0,000^{\mathrm{b}}$ \\
& Residual & 47,428 & 216 & 0,220 & & \\
& Total & 56,190 & 220 & & & \\
\hline
\end{tabular}

a. Dependent Variable: Perilaku Menabung

b. Predictors: (Constant), Kontrol Diri, Melek Finansial, Teman Sebaya, Sosialisasi Orang Tua Sumber: Data primer yang diolah, 2015

Tabel 7

Uji Regresi

\begin{tabular}{|c|c|c|c|c|c|c|c|}
\hline \multirow[t]{2}{*}{ Model } & \multicolumn{2}{|c|}{$\begin{array}{c}\text { Unstandardized } \\
\text { Coefficients }\end{array}$} & \multirow{2}{*}{$\begin{array}{c}\begin{array}{c}\text { Standardized } \\
\text { Coefficients }\end{array} \\
\text { Beta } \\
\end{array}$} & \multirow[t]{2}{*}{$\mathbf{T}$} & \multirow[t]{2}{*}{ Sig. } & \multicolumn{2}{|c|}{$\begin{array}{c}\text { Collinearity } \\
\text { Statistics }\end{array}$} \\
\hline & B & Std. Error & & & & Tolerance & VIF \\
\hline (Constant) & 2,996 & 0,251 & & 11,931 & 0,000 & & \\
\hline Melek Finansial & 0,129 & 0,054 & 0,159 & 2,365 & 0,019 & 0,863 & 1,159 \\
\hline $\begin{array}{l}\text { Sosilaisasi Orang } \\
\text { Tua }\end{array}$ & 0,130 & 0,051 & 0,175 & 2,565 & 0,011 & 0,840 & 1,191 \\
\hline $\begin{array}{l}\text { Pengaruh Teman } \\
\text { Sebaya }\end{array}$ & 0,040 & 0,038 & 0,068 & 1,044 & 0,298 & 0,925 & 1,082 \\
\hline Kontrol Diri & $-0,144$ & 0,039 & $-0,240$ & $-3,674$ & 0,000 & 0,918 & 1,090 \\
\hline
\end{tabular}

a. Dependent Variable: Perilaku Menabung

Sumber: Data primer yang diolah, 2015 